CZASOPISMO INŻYNIERII LADDOWEJ, ŚRODOWISKA I ARCHITEKTURY JOURNAL OF CIVIL ENGINEERING, ENVIRONMENT AND ARCHITECTURE

JCEEA, t. XXXII, z. 62 (3/II/15), lipiec-wrzesień 2015, s. 7-24

\author{
Jacek ABRAMCZYK
}

\title{
A WAY OF GEOMETRICAL SHAPING EFFECTIVE SHELL FORMS
}

\begin{abstract}
The main content of the paper is a presentation of a way of arranging individual light gauge steel shells in the three-dimensional space to obtain a structure whose general shape corresponds to a regular surface called a base surface characterized by any sign of the Gaussian curvature. The way enables us to achieve: a) an integration of the shape and locations of any number of elements of a shaped building object including walls, windows, roof shell stripes by a diversification of their inclination to the vertical direction and a horizontal plane, b) an effective structural work of the shell folds of the deformed sheets producing individual shells, c) an effective arrangement of the stripes passing crosswise the whole structure by means of the base surface, d) an effective cover of the shell strips with the shell sheets. These aims were achieved by means of auxiliary polyhedral compositions whose side and edges are close to planes and straight lines normal to the base surface as accurate as possible at the point chosen initially. In the next stage, the directrices of the stripes are determined on the planes of this controlling structure composed of the above auxiliary compositions. The models of the stripes are fixed on the base of these directrices so that each model would be contained in one controlling composition. The proposed way can be easily extended over more complicated shell structures, including segment shell structure, characterized by a great integration of any number of elements of a building object.
\end{abstract}

Keywords: light gauge steel shells, stripe structures, free deformation

\section{Introduction - Free Shell Structures}

Flat sheets are connected one to another by their longitudinal edges to obtain a stripe, which can be easily transformed into shell forms-individual shell, see Fig. 1. While transforming a freedom of the transversal width increments of the stripe folds is assured, so their transformation is called free deformations $[4,15]$. There are three basic free deformations: a) free bend, b) free twist and c) a bend-twist deformation, see Fig. 2.

\footnotetext{
${ }^{1}$ Author for correspondence: Jacek Abramczyk, Rzeszow University of Technology, ul. Poznańska 2, pok. 217, 35-959 Rzeszów, +17 865 1307, jacabram@prz.edu.pl.
} 


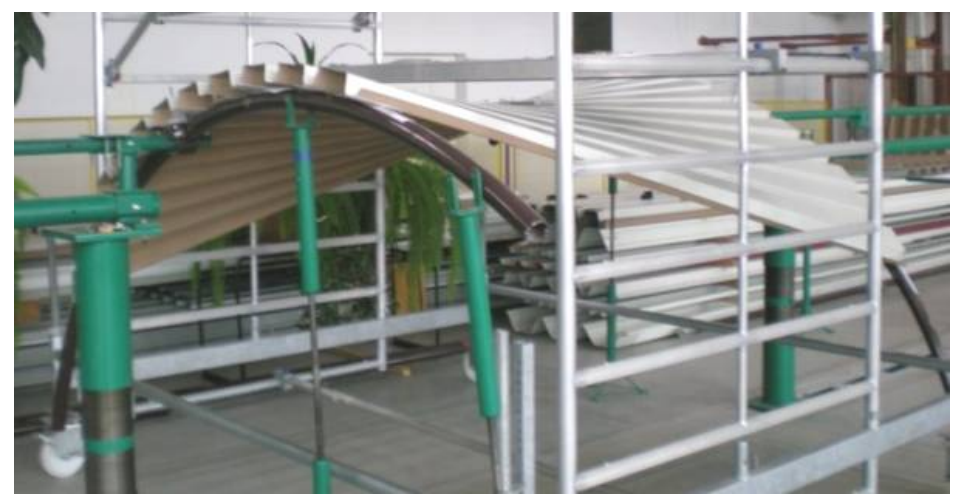

Fig. 1. The view of a shell strip [4]

Rys. 1. Model powłokowego pasma

a)

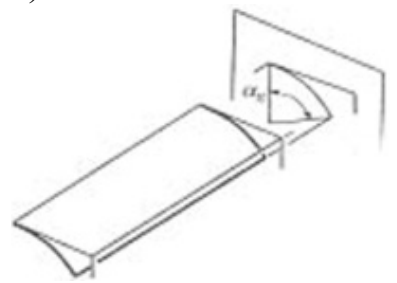

b)

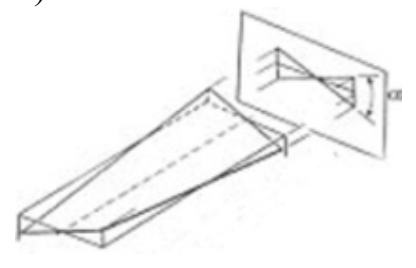

c)

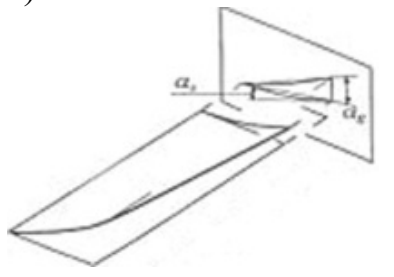

Fig. 2. Three basic fee deformations: a) bent, b) twist and c) bent twist

Rys. 2. Trzy podstawowe deformacje swobodne: a) giętna, b) skrętna, c) giętno-skrętna

Because the shell sheets (shell folds) take diversified positions toward the vertical direction and a horizontal plane, oblique at most, then they experience a mutual influence and, in the end, the mutual displacement of their folds axes along their directions under the influence of their own weight and forces acting during assembling the folds to the shell directrices. Such a displacement of adjacent shell folds is called a cut deformation, see Fig. 3.a, [1].Another forced deformation is called a press-stretch deformation, see Fig. 3.b, which causes a change of the fold width along the directrix direction.

Folds in the same shell may be subject to deformations of various types and values $[2,3]$. Therefore, the mutual position of the directrices supporting the same strip may be almost free but the crosswise ends of the shell fold may require oblique cutting in conformity with the directrices directions [1]. 


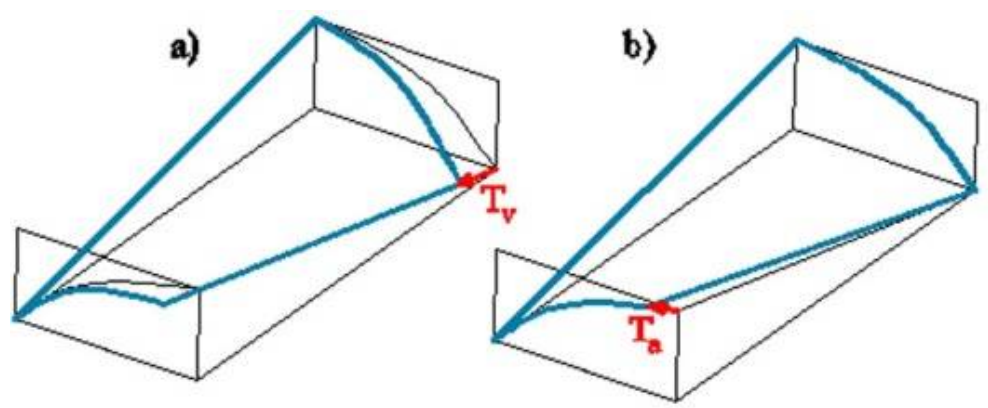

Fig. 3. Two types of additional, forced deformations: a) cut deformation, b) press-stretch deformation

Rys. 3. Dwa rodzaje dodatkowych deformacji wymuszających: a) deformacja ścinająca, b) deformacja ściskająca-rozciągająca

The lengths of these shell folds cannot be as big as one likes because of the transport and shell shape changes restrictions [1]. For example, if we want to receive a big degree of the deformation the length may be curtailed. Thus, the stripes should be putted together to obtain a span and attractiveness greater than in the case of an individual shell [4].

We may join the stripes to obtain the compound shell characterized by very attractive and original shell form whose the Gaussian curvature is of free sign and value in opposition to an individual shell whose form have to be a continue sector of a ruled surface characterized by the non-positive Gaussian curvature $[2,3]$.

The main aim of linking many individual shells - stripes is to get a shell structure whose general form is close to geometrical surface being characterized by the positive Gaussian curvature and regular pattern made of either shared edges or flat areas between the segments of the structure, see Fig 4.
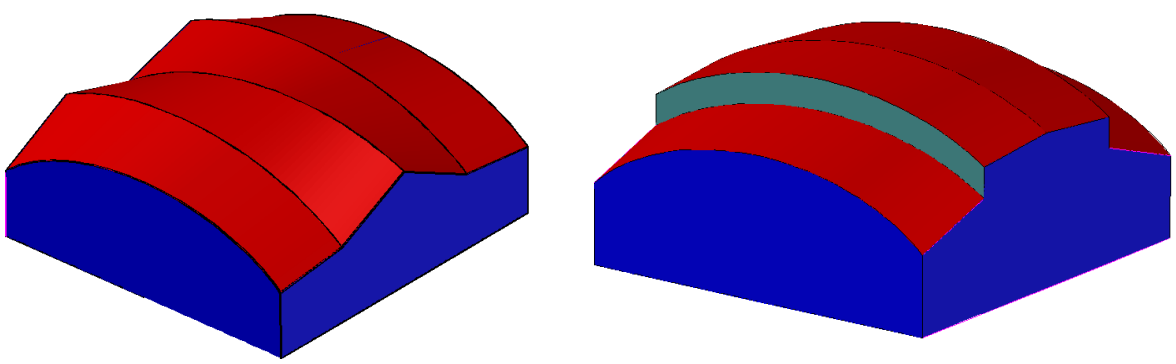

Fig. 4. Models of stripe shell structures characterized by shared or separated and displaced directrices of the adjacent segments

Rys. 4. Modele powłokowych struktur pasmowych charakteryzujących się współdzielonymi lub rozsuniętymi kierownicami sąsiednich segmentów 
The easiest form of a building object covered with a strip shell structure can be obtained by locating the directrices and walls on vertical planes parallel to each other [5], see Fig. 5.
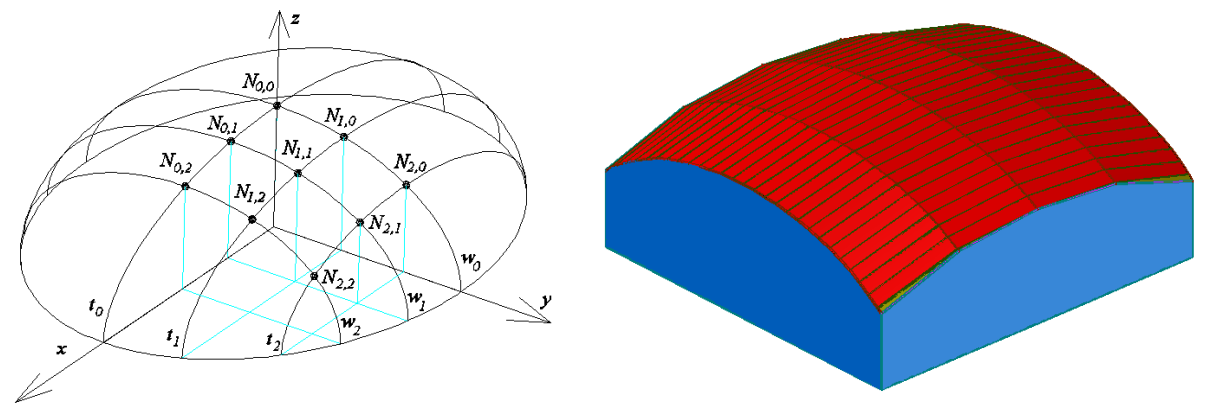

Fig. 5. The way of creating and visualization of a continue strip shell structure characterized by vertical location of its directrices

Rys. 5. Sposób tworzenia i wizualizacja ciagłej, pasmowej struktury powłokowej charakteryzującej się pionowym położeniem kierownic

The most attractive shell forms are received by inclining walls including gable walls of a building object to vertical planes obliquely and, next, locating the directrices on the wall planes, Fig. 6. Additionally, the gable walls may be divided into two symmetrical parts [5], Fig. 7.
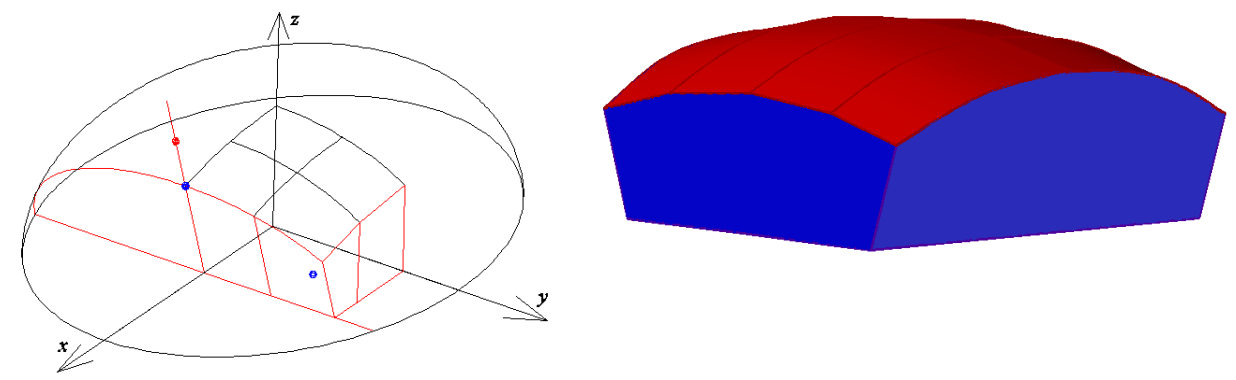

Fig. 6. The way of creation and visualization a shell structure having two oblique flat gable walls

Rys. 6. Sposób tworzenia i wizualizacja struktury powłokowej posiadającej dwie ukośne ściany szczytowe 

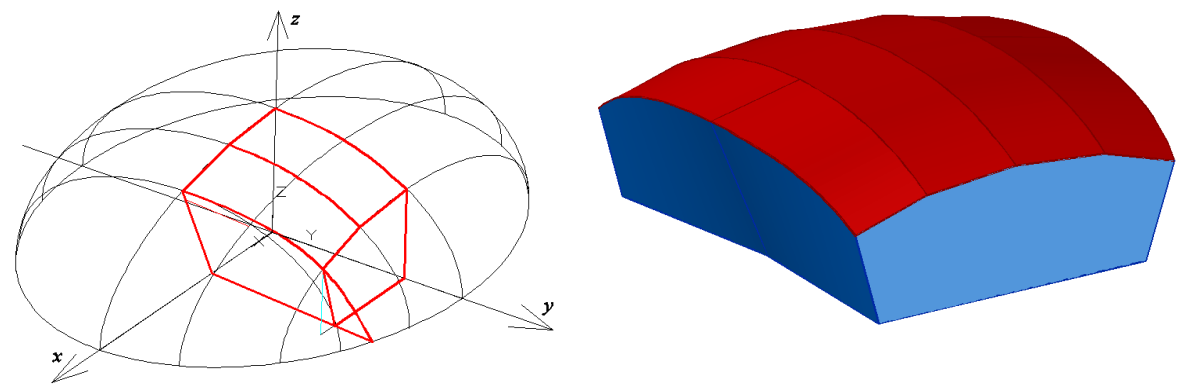

Fig. 7. The way of creating and visualization a shell structure having two oblique gable walls composed of two flat pieces symmetrical toward the plane $(x, z)$

Rys. 7. Sposób tworzenia i wizualizacja struktury powłokowej posiadającej dwie ukośne ściany szczytowe złożone $\mathrm{z}$ dwóch części symetrycznych względem płaszczyzny $(x, z)$

The innovative character of the way rely on integrating the form of a whole building object that is referring the locations and shapes of its directrices to the locations and shapes of its walls and windows having regard to: a) an effective structural work of the deformed folds, b) an effective arrangement of the stripes toward a base surface, c) an effective cover of the shell strips with the deformed sheets.

We can optimize shapes and location of the shell building objects [6], for example, by minimizing values of the angle measures of the inclination of wall's edges and chosen straight lines normal for the stripe's surfaces.

\section{The Assumptions of the Way}

A regular, geometrical surface called a base surface is used to arrange shell stripes in the three dimensional space. In the example presented bellow, this surface is an non-rotational ellipsoid $\sigma[11,13,14]$ expressed as:

$$
\frac{x^{2}}{a^{2}}+\frac{y^{2}}{b^{2}}+\frac{z^{2}}{c^{2}}=1
$$

where: $a=24000 \mathrm{~mm}, b=18000 \mathrm{~mm}, c=11000 \mathrm{~mm}$,

$$
x, y, z-\text { variables. }
$$

To determine the shapes and locations of a shell structure directrices and stripes, lines on $\sigma$ are fixed in planes perpendicular and parallel to the axes of the coordinate system $[x, y, z]$. The straight lines tangent and normal to $\sigma$ are led through the points of their intersection, Fig. 8.

The above lines can be used for integrating any number of elements of a building object. This integration is achieved by division of the elevation walls into flat areas included in planes normal to the base surface or in planes 
approximating these ones. The stripe directrices of the shall structures are also contained in the planes of the walls.
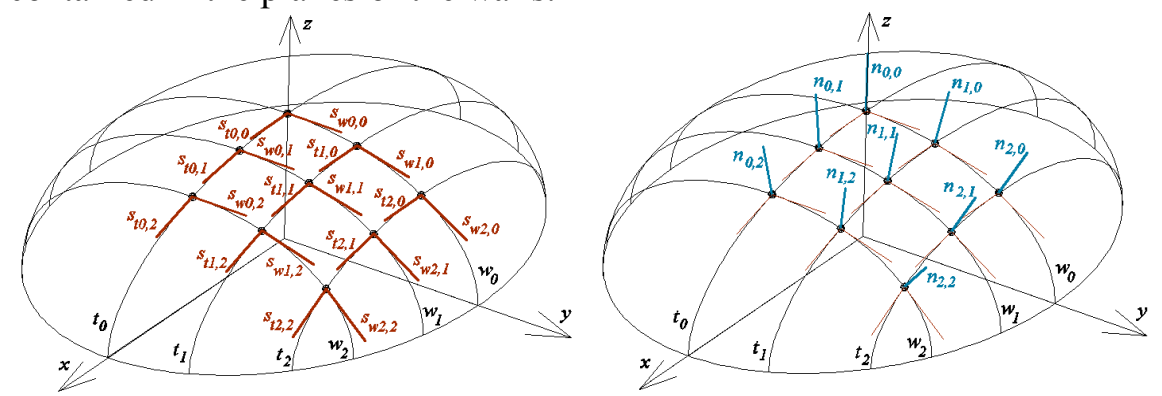

Fig. 8. The straight lines tangent $s_{t i, j}, s_{w i, j}$ and normal $n_{i, j}$ to the ellipsoid $\sigma$ at the points $N_{i, j}$

Rys. 8. Linie styczne $s_{t i, j}, s_{w i, j}$ i normalne $n_{i, j}$ do elipsoidy $\sigma$ w punktach $N_{i, j}$

The next assumption $[8,9,18]$ of the way is to get: a) an effective initial deformations resulting from assembling sheets to the strip diretrices, b) an effective arrangement of the stripes toward a base surface, c) an effective cover of the shell strips with the deformed sheets.

The effective initial deformations of the flat sheets caused by assembling sheets to the strip diretrices consist in assuring a freedom of transversal width increments of each shell fold and a possible small effort $[4,15]$ of these shell folds so that they have an ability of bearing possible great functional loads.

The effective arrangement of the stripes toward the base surface is relied on exploiting the straight lines and planes normal to this surface to obtain the border lines of the stripes including directices being lain on these planes or located and directed toward these planes [3].

The effective covering the shell strips with the deformed sheets consists in assuring that the shell sheets after spreading on the shell directrices are going to cover the stripe area possibly tightly as well as their crosswise ends will be possible close to the locations and directions of the directrices [1].

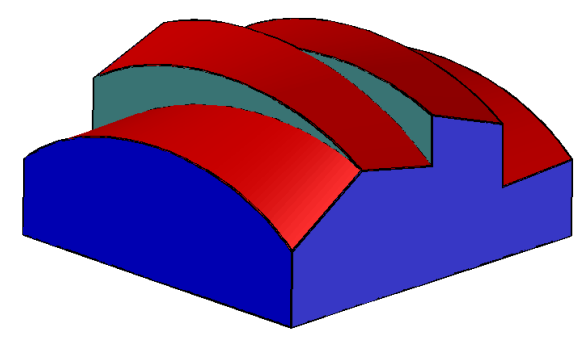

Fig. 9. A model of a discontinuous strip shell structure characterized by the directices separated from each other by translating and rotating

Rys. 9. Model nieciągłej struktury powłokowej, której kierownice rozsunięto i obrócono 
It is possible to increase the diversity and the attractiveness of the free and original general forms of the shell structures by splitting the shared directrices of the adjacent stripes by dint of such displacements as translations or rotations $[5,12,16]$, Figs. $4,9$.

In general, we obtain the ellipse $w_{j}$ as the result of intersection of the base ellipsoid $\sigma$ with a plane parallel to the plane $(y, z)$ of the local coordinate system $[x, y, z]$ of $\sigma$. In the considered example, the mathematic representation of each directrix of a strip created on the base of this ellipsoid [17] in its local coordinate system is as follows:

$$
\begin{aligned}
& x_{o}=x N_{0, j} \\
& y_{o}=b_{w j} \cdot \cos \left(\omega_{j}\right) \\
& z_{o}=c_{w j} \cdot \sin \left(\omega_{j}\right)
\end{aligned}
$$

where: $b_{w j}=b \cdot \sqrt{1-\frac{x N_{0, j}{ }^{2}}{a^{2}}}, c_{w j}=c \cdot \sqrt{1-\frac{x N_{0, j}{ }^{2}}{a^{2}}}, \omega_{j}$ - angular parameter.

If we want to obtain the equations of these directrices in the local coordinate system of $\sigma$, then we will use the transformation formula of the local system of the ellipse $w_{j}$ into the local system of $\sigma$ given by:

$$
\begin{aligned}
& x=x_{o} \\
& y=y_{o} \cdot \cos (\alpha)+\left(z_{o}-w_{z}\right) \cdot \sin (\alpha) \\
& z=-y_{o} \cdot \sin (\alpha)+\left(z_{o}-w_{z}\right) \cdot \cos (\alpha) .
\end{aligned}
$$

The equation system (3) describes also a transformation of the coordinate of a point $P(x, y, z)$ from the coordinate system $\left[x_{o}, y_{o}, z_{o}\right]$ into the coordinate system $[x, y, z]$. This transformation exploits the composition of the translation by the vector $\vec{w}=\left[0,0, w_{z}\right]$ and rotation by the angle $\alpha$ around the axis $x_{w}$ being the result of the displacement of the axis $x$ by the vector $\vec{w}$. This transformation enables us to exploit the system (3) in determining not only the equations of each transformed strip directrices in the ellipsoid coordinate system but also the locations of each ruling of the considered strips.

The final system of three parametric equations of the ellipse $w_{j}$ in $[x, y, z]$ are as follows

$$
\begin{aligned}
& x=x N_{0, j} \\
& y=b_{w j} \cdot \cos \left(\omega_{j}\right) \cdot \cos (\alpha)+\left(c_{w j} \cdot \sin \left(\omega_{j}\right)-w_{z}\right) \cdot \sin (\alpha) \\
& z=-b_{w j} \cdot \cos \left(\omega_{j}\right) \cdot \sin (\alpha)+\left(c_{w j} \cdot \sin \left(\omega_{j}\right)-w_{z}\right) \cdot \cos (\alpha) .
\end{aligned}
$$




\section{The Presentation of the Way on the Base of Stripe Structures}

With respect to the restrictions referring to the fold shape changes while assembling them to the shell directrices it was decided that the activities provided by the way algorithm have to be devidet into two essential stages.

The first stage is produced by the action leading to creating a polyhedral structure called a controlling structure whose planes separate the individual stripes of the shell structure from each other. The controlling structure delimits crosswise "cells" in the space, in which the strips satisfying the restrictions referring to the shape changes are located. In the second stage the shell stripes are positioned in these "cells" by means of flat directrices being created on the planes of the controlling structure.

To obtain a first stripe - Stripe 1 of a shell structure, arranged toward the ellipsoid (1), we have to replace the pairs of adjacent skew lines: $\left(n_{0,1}, n_{1,1}\right)$, $\left(n_{1,1}, n_{2,1}\right)$ passing through the points: $N_{0,1}, N_{1,1}$ and $N_{1,1}, N_{2,1}$. The points $H_{w 1,1}$, $H_{w 2,1}$ are taken on two straight lines $n_{H w 1,1}, n_{H w 2,1}$ perpendicular to the pairs $\left(n_{0,1}, n_{1,1}\right),\left(n_{1,1}, n_{2,1}\right)$ and intersecting the straight lines of these pairs at points $H_{w 0,1 \_1,1}, H_{w 1,1 \_1,1}$ and $H_{w 1,1 \_2,1}, H_{w 2,1 \_2,1}$, Fig. 10 , so that the positions of the points $H_{w 1,1}, H_{w 2,1}$ are between the points, $H_{w 0,1 \_1,1}, H_{w 1,1 \_1,1}$ and $H_{w 1,1 \_2,1}$, $H_{w 2,1 \_2,1}$, respectively. In our examples, the values of the division ratios $\mathrm{w}_{H w i, j}$ of all sections $H_{w i-1, j_{-}, j, j} H_{w i, j \_i, j}$ (for $i=1,2$ and $j=1$ ) by the points $H_{w i, j}$ are equal to 0.5 to get the directrices planes close to normal to the base ellipsoid, so the above mentioned points $H_{w 1,1}, H_{w 2,1}$ are taken in the middle of the segments $H_{w 0,1 \_1,1} H_{w 1,1 \_1,1}$ and $H_{w 1,1 \_2,1} H_{w 2,1 \_2,1}$.

The tetrads of the points determine the planes $\zeta_{w 1,1}, \zeta_{w 2,1}$ intersected themselves in the edge $h_{1,1}$, Fig. 12. This way that is by means of such pairs of planes $\zeta_{w i, j}, \zeta_{w i+1, j}$ the side edges of the created control structure have to be fixed.

The positions of points $H_{w 1,1}, H_{w 2,1}$ on the segments $H_{w 0,1 \_1,1} H_{w 1,1 \_1,1}$ and $H_{w 1,12,1} H_{w 2,1 \_2,1}$ can be optimized, so that the directions of the straight lines $h_{i, j}$ would be possible close to $n_{i, j}$ normal to the reference ellipsoid (1). The meaning of the indexes of the symbol $H_{w i-1, j_{-}, j}$ is as follows. The symbol $w$ means that this element is associated with the arches $w_{j}$ of $\sigma$, and $i-1, j$ means that the point belongs to straight line $n_{i-1, j}$, and $i, j$ means that this point takes part in determining the point $H_{w i, j}$.

Faces of the controlling structure is contained in the plane $\zeta_{w i, j}\left(N_{i-1, j}, N_{i, j}\right.$, $\left.H_{w i, j}\right)$. However, the line of the intersection of the pair of the adjacent planes $\zeta_{w i-1, j}, \zeta_{w i, j}(j=$ const $)$ passing through the point $N_{i-1, j}$ is a side edge of the controlling structure. 


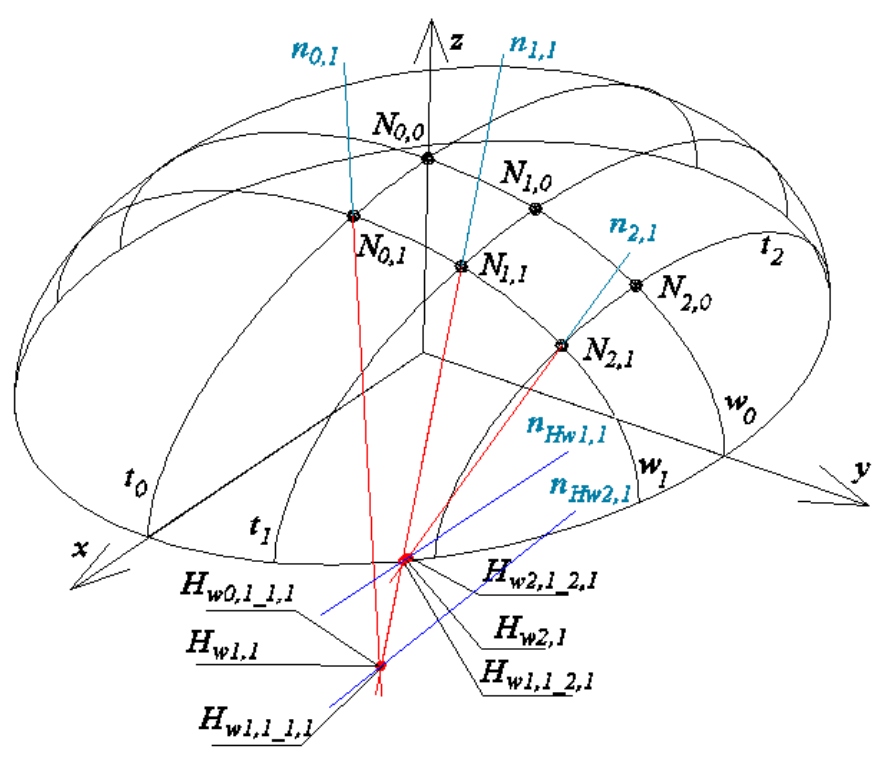

Fig. 10. Creation of the controlling structure planes of the first strip of an effective shell structure Rys. 10. Tworzenie struktury sterującej pierwszego pasma efektywnej struktury powłokowej

The controlling composition $\Gamma_{j}$ is the sum of inseparable triangles $\sum_{i=1}^{n} N_{i-1, j} N_{i, j} H_{w i, j}$.

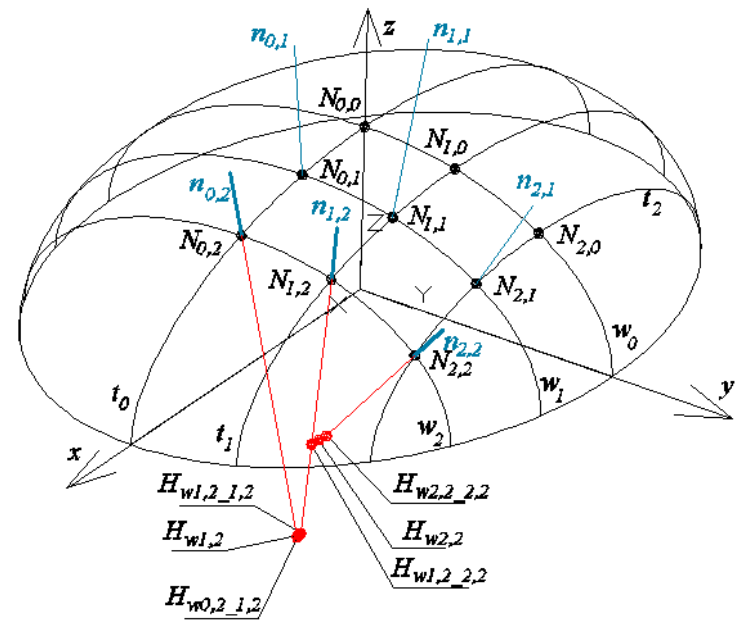

Fig. 11. The creation of the controlling structure of the second strip of an effective shell structure Rys. 11. Tworzenie struktury sterującej drugiego pasma efektywnej struktury powłokowej 
We should create all controlling compositions in the analogous way as $\Gamma_{l}$, Fig. 11. The coordinate of points $N_{i, j}$ are shown in Tab. 1.

Table 1. The coordinates of the chosen points $N_{i, j}$ on the base ellipsoid $\sigma$ Tabela 1. Współrzędne punktów $N_{i, j}$ wybranych na elipsoidzie bazowej $\sigma$

\begin{tabular}{|c|c|c|c|}
\hline Point & $\boldsymbol{x}$ [mm] & $\boldsymbol{y}[\mathbf{m m}]$ & $\boldsymbol{z}[\mathbf{m m}]$ \\
\hline $\boldsymbol{N}_{\mathbf{0 , 0}}$ & 0.00000 & 0.00000 & 11000 \\
\hline $\boldsymbol{N}_{\mathbf{1 , 0}}$ & 0.00000 & 6459.0 & 10267 \\
\hline $\boldsymbol{N}_{\mathbf{2}, \mathbf{0}}$ & 0.00000 & 12515 & 7906.0 \\
\hline $\boldsymbol{N}_{\mathbf{0 , 1}}$ & 6487.0 & 0.00000 & 10590 \\
\hline $\boldsymbol{N}_{\mathbf{0 , 2}}$ & 12855 & 0.00000 & 9289.0 \\
\hline $\boldsymbol{N}_{\mathbf{1 , 1}}$ & 6487.0 & 6459.0 & 9828.0 \\
\hline $\boldsymbol{N}_{\mathbf{2}, \mathbf{1}}$ & 6487.0 & 12515 & 7326.0 \\
\hline $\boldsymbol{N}_{\mathbf{1 , 2}}$ & 12855 & 6459.0 & 8409.0 \\
\hline $\boldsymbol{N}_{\mathbf{2 , 2}}$ & 12855 & 12515 & 5272.0 \\
\hline
\end{tabular}

The controlling structure $\Gamma$ of the strip shell structure is most often built from separated stripes $\Gamma_{j}$ of triangles, see Figs. 10, 11.

Let us distinguish the points $H_{w i, j}, H_{w i, j}, i, j$ (for $i=0,1,2 ; j=0,1$ ), Fig. 11, whose construction is presented below and coordinates were placed in Tab. 2.

Table 2. The coordinates of the points $N_{i, j}$ chosen on the reference ellipsoid $\sigma$ Tabela 2. Współrzędne punktów $N_{i, j}$ wybranych na elipsoidzie bazowej $\sigma$

\begin{tabular}{|c|c|c|c|}
\hline Point & $x[\mathrm{~mm}]$ & $y[\mathrm{~mm}]$ & $z[\mathrm{~mm}]$ \\
\hline$H_{w 0,1 \_1,1}$ & 3003.6 & 0.0 & -16481.6 \\
\hline$H_{w 1,1 \_1,1}$ & 2841.8 & 6.6 & -16460.8 \\
\hline$H_{w 1,1}$ & 2922.7 & 3.3 & -16471.2 \\
\hline$H_{w 1,1 \_2,1}$ & 3792.0 & 1688.3 & -9608.6 \\
\hline$H_{w 2,1 \_, 1}$ & 3346.1 & 1742.1 & -9560.0 \\
\hline$H_{w 2,1}$ & 3569.0 & 1715.2 & -9584.3 \\
\hline$H_{w 0,2 \_1,2}$ & 6062.6 & 0.0 & -14076.1 \\
\hline$H_{w 1,2 \_1,2}$ & 5670.8 & 41.6 & -13962.1 \\
\hline$H_{w 1,2}$ & 5866.7 & 20.8 & -14019.1 \\
\hline$H_{w 1,2 \_2,2}$ & 8187.2 & 2289.1 & -6126.8 \\
\hline$H_{w 2,2 \_2,2}$ & 7139.8 & 2622.9 & -5886.2 \\
\hline$H_{w 2,2}$ & 7663.5 & 2456.0 & -6006.5 \\
\hline
\end{tabular}

In the below example two consecutive normal straight lines $\left\{n_{i-1, j}, n_{i, j}\right\}$ arranged along the curves $w_{j}$ are examined. In addition, the analogical pairs 
of consecutive normal straight lines arranged along $t_{i}$ will be considered to get segment shell structures but this issue goes beyond the scope of the paper.

Two pairs of the planes $\zeta_{w 1,1}, \zeta_{w 2,1}$ and $\zeta_{w 1,2}, \zeta_{w 2,2}$ intersect themselves in the edges $h_{1,1}, h_{1,2}$, Fig. 12. The planes $\zeta_{w 1,1}, \zeta_{w 1,2}$ intersect the plane $(x, z)$ in the edges $h_{0,1}, h_{0,2}$. However, the planes $\zeta_{w 2,1}, \zeta_{w 2,2}$ intersect the plane of the ellipse $t_{2}$ in the edges $h_{2,1}, h_{2,2}$.

An edge model one of four symmetric pieces of a building object roofed with a stripe shell structure is presented in Fig. 13. The suitable sections of the edges $h_{1,1}, h_{0,2}, h_{2,0}, h_{1,2}, h_{2,2}$ of this model are the edges of the walls or the windows of the final object. The planes $\zeta_{w i, j}$ intersect the ellipsoid $\sigma$ in curves being the new directrices different from the ellipses $w_{j}$. In our example, see Fig. 13, the directrices of each strip are composed of two symmetrical curves having one shared end making the disturbance of the smoothness of the strip model. In the case of our ellipsoid $\sigma$ this disturbance is not very significant and we decided to put together four congruent parts to get the symmetric model of a stripe shell structure.
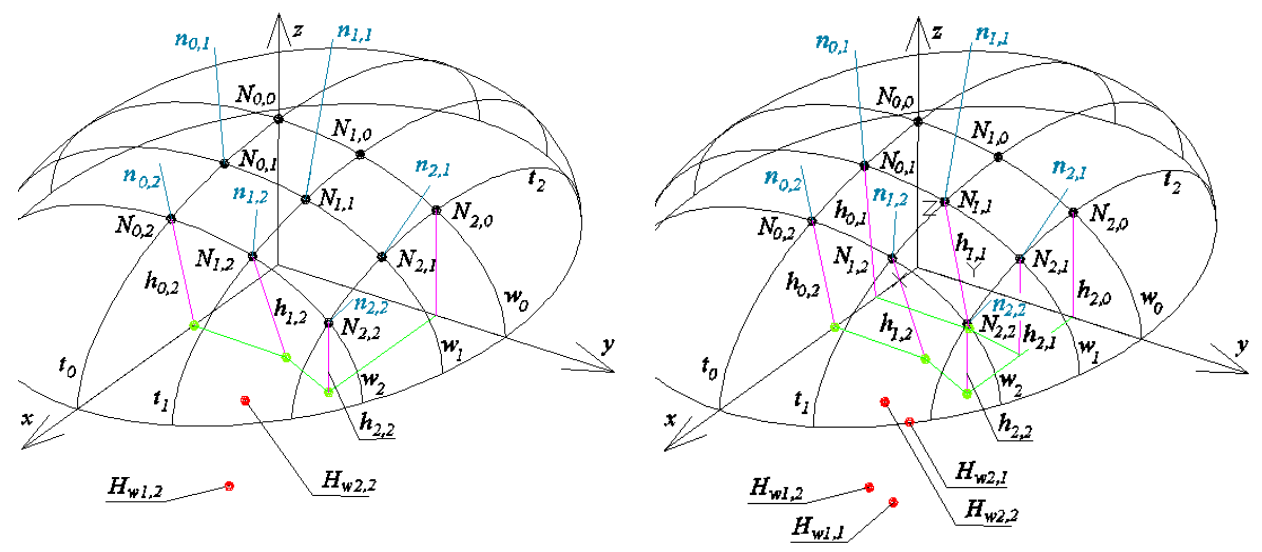

Fig. 12. Creation of the side edges of a controlling structure of an effective strip shell structure

Rys. 12. Tworzenie struktury sterującej efektywnej pasmowej struktury powłokowej 

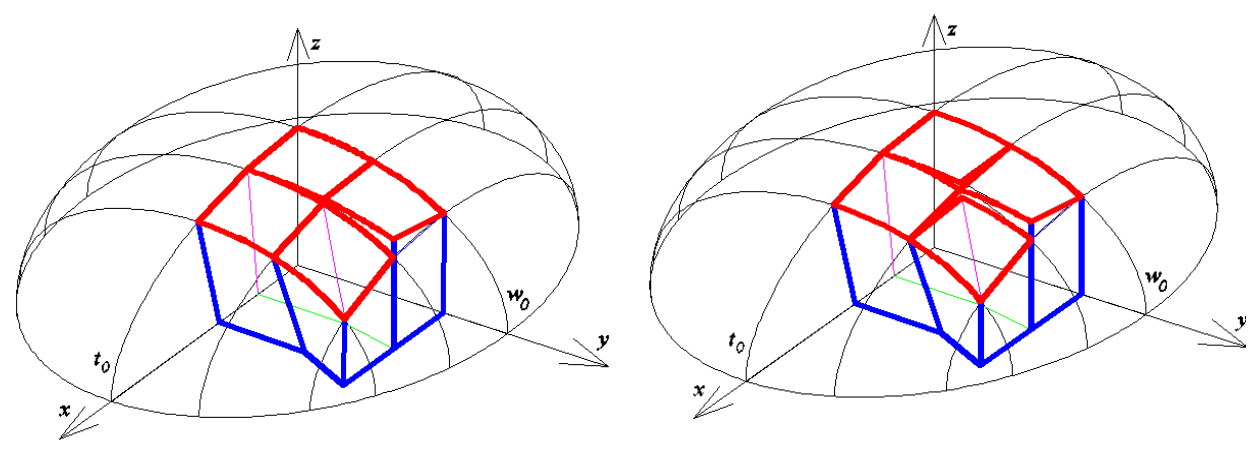

Fig. 13. Geometric forms of two shell structures created with the considered controlling structure

Rys. 13. Formy geometryczne dwóch struktur powłokowych zbudowanych za pomocą rozpatrywanej struktury sterującej

It is possible to substitute the elliptical directrices of the shell strips by arches or algebraic planar or spatial lines. Particularly, in this last case we get an easy way which lets us keep the smoothness along a whole strip as well as to obtain the directrices being close to the planes $\zeta_{w i j}$.

Because the Reichhart's computer program calculating an arrangement of points of assembling the crosswise folds ends to the shell directrces requires accepting mathematic equations of these directrices, then the formulae describing the most general transformation of the planar freely located directrices from their coordinate systems into the local system $[x, y, z]$ of ellipsoid $\sigma$ is going to be presented below. The coordinates of any point of this line in its coordinate system are denoted by $x_{L}, y_{L}, z_{L}$, but its coordinates in the system $[x, y, z]$ are denoted by $x, y, z$.

Let us accept that the directrix is a half of the ellipse being represented by

$$
\begin{aligned}
& x_{L}=b_{w j} \cdot \cos \left(\omega_{j}\right) \\
& y_{L}=y N_{0, j} \\
& z_{L}=c_{w j} \cdot \sin \left(\omega_{j}\right),
\end{aligned}
$$

in its local system and we must transformed its equation system into the system $[x, y, z]$, see Fig. 14. In general, this transformation requires executing the following five stiff motions of $\left[x_{L}, y_{L}, z_{L}\right]$ :

a) the rotation $\mathrm{O}_{\mathrm{x} 1}$ of $\left[x_{L}, y_{L}, z_{L}\right]$ into the position $\left[x_{1}, y_{1}, z_{1}\right]$ around the axis $x_{L}$ at the angle $\vec{\beta}_{x_{1}}$, where $\xi_{L}=\left(x_{L}, z_{L}\right)$; 
b) the translation $T_{z 2}$ of $\left[x_{1}, y_{1}, z_{1}\right]$ into the position $\left[x_{2}, y_{2}, z_{2}\right]$ by vector $\vec{w}_{z 2}$ along the axis $z_{1}$;

c) the rotation $\mathrm{O}_{\mathrm{y} 3}$ of $\left[x_{2}, y_{2}, z_{2}\right]$ into the position $\left[x_{3}, y_{3}, z_{3}\right]$ around the axis $y_{2}$ by the angle $\vec{\beta}_{y 3}$ which can be measured between $\xi_{y z}$, and $\xi_{L}$, where $\xi_{y, z}=(y, z)$;

d) the rotation $\mathrm{O}_{\mathrm{x} 4}$ of $\left[x_{3}, y_{3}, z_{3}\right]$ into the position $\left[x_{4}, y_{4}, z_{4}\right]$ around the axis $x_{3}$ by the angle $\vec{\beta}_{x 4}$;

e) the composition $\mathrm{T}_{\mathrm{yz}}=\mathrm{T}_{\mathrm{y}} \mathrm{T}_{\mathrm{z}}$ of two translations of $\left[x_{4}, y_{4}, z_{4}\right]$ into $[x, y, z]$ by the vector $\vec{w}_{\mathrm{yz}}=\vec{w}_{\mathrm{y}}+\vec{w}_{\mathrm{z}}$ where the direction vectors are parallel to the axes $y, z$ of $[x, y, z]$.

The rotation $\mathrm{O}_{\mathrm{x} 1}$ of $\left[x_{L}, y_{L}, z_{L}\right]$ into the position $\left[x_{1}, y_{1}, z_{1}\right]$ about the axis $x_{L}$ at the angle $\vec{\beta}_{x 1}$ is represented by

$$
\begin{aligned}
& x_{1}=x_{L} \\
& y_{1}=y_{L} \cdot \cos \left(\beta_{x 1}\right)+z_{L} \cdot \sin \left(\beta_{x 1}\right) \\
& z_{1}=-y_{L} \cdot \sin \left(\beta_{x 1}\right)+z_{L} \cdot \cos \left(\beta_{x 1}\right) .
\end{aligned}
$$

The edge $k_{r}$ of the intersection of the planes $\xi_{y z}$ and $\xi_{L}$ is parallel to the axis $y_{1}$.

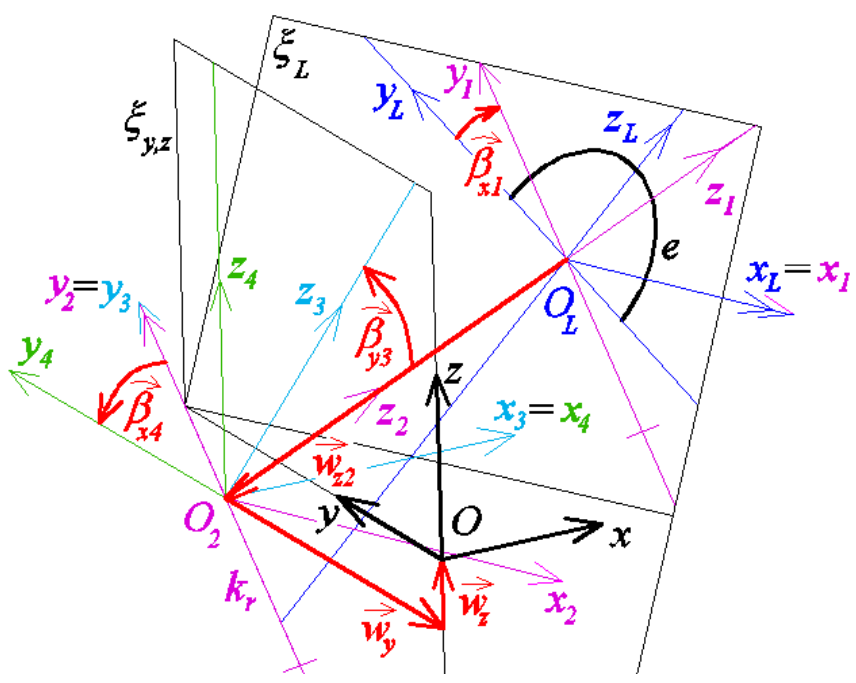

Fig. 14. The visualization of the transformation of the local coordinate system $\left[x_{L}, y_{L}, z_{L}\right]$ of the directrix $e$ into the coordinate system $[x, y, z]$ being lain freely in the three-dimensional space

Rys. 14. Wizualizacja transformacji lokalnego układu współrzędnych $\left[x_{L}, y_{L}, z_{L}\right]$ kierownicy $e$ do układu współrzędnych $[x, y, z]$ położonego dowolnie w trójwymiarowej przestrzeni 
The translation $\mathrm{T}_{\mathrm{z} 2}$ of $\left[x_{1}, y_{1}, z_{1}\right]$ into the position $\left[x_{2}, y_{2}, z_{2}\right]$ by vector $\vec{w}_{\mathrm{z} 2}$ along the axis $z_{1}$ is represented by

$$
\begin{aligned}
& x_{2}=x_{1} \\
& y_{2}=y_{1} \\
& z_{2}=z_{1}-w_{z 2} .
\end{aligned}
$$

The rotation $\mathrm{O}_{\mathrm{y} 3}$ of $\left[x_{2}, y_{2}, z_{2}\right]$ into the position $\left[x_{3}, y_{3}, z_{3}\right]$ around the axis $y_{2}$ by the angle $\vec{\beta}_{y 3}$ is represented by

$$
\begin{aligned}
& x_{3}=x_{2} \cdot \cos \left(\beta_{y 3}\right)+z_{2} \cdot \sin \left(\beta_{y 3}\right) \\
& y_{3}=y_{2} \\
& z_{3}=-x_{2} \cdot \sin \left(\beta_{y 3}\right)+z_{2} \cdot \cos \left(\beta_{y 3}\right) .
\end{aligned}
$$

The the rotation $\mathrm{O}_{x 4}$ of $\left[x_{3}, y_{3}, z_{3}\right]$ into the position $\left[x_{4}, y_{4}, z_{4}\right]$ around the axis $x_{3}$ by the angle $\vec{\beta}_{x 4}$ is represented by

$$
\begin{aligned}
& x_{4}=x_{3} \\
& y_{4}=y_{3} \cdot \cos \left(\beta_{x 4}\right)+z_{3} \cdot \sin \left(\beta_{x 4}\right) \\
& z_{4}=-y_{3} \cdot \sin \left(\beta_{x 4}\right)+z_{3} \cdot \cos \left(\beta_{x 4}\right) .
\end{aligned}
$$

The composition $\mathrm{T}_{\mathrm{yz}}=\mathrm{T}_{\mathrm{y}} \mathrm{T}_{\mathrm{z}}$ of two translations of $\left[x_{4}, y_{4}, z_{4}\right]$ into $[x, y, z]$ by the vector $\vec{w}_{\mathrm{yz}}$ whose component vectors $\vec{w}_{\mathrm{y}}, \vec{w}_{\mathrm{z}}$ are parallel to the axes $y$, $z$ of $[x, y, z]$ is represented by

$$
\begin{aligned}
& x=x_{4} \\
& y=y_{4}-w_{y} \\
& z=z_{4}-w_{z} .
\end{aligned}
$$

As the result of the composition of the above transformation formulae the following system of three equations was obtained as

$$
\begin{aligned}
& x=a_{1} \cdot x_{L}+b_{1} \cdot y_{L}+c_{1} \cdot z_{L}+d_{1} \\
& y=a_{2} \cdot x_{L}+b_{2} \cdot y_{L}+c_{2} \cdot z_{L}+d_{2} \\
& z=a_{3} \cdot x_{L}+b_{3} \cdot y_{L}+c_{3} \cdot z_{L}+d_{3},
\end{aligned}
$$

where:

$a_{1}=\cos \left(\beta_{y 3}\right)$

$b_{1}=-\sin \left(\beta_{x 1}\right) \cdot \sin \left(\beta_{y 3}\right)$

$c_{1}=\cos \left(\beta_{x l}\right) \cdot \sin \left(\beta_{y 3}\right)$ 


$$
\begin{aligned}
& d_{1}=-\sin \left(\beta_{y 3}\right) \cdot w_{z 2} \\
& a_{2}=-\sin \left(\beta_{y 3}\right) \cdot \sin \left(\beta_{x 4}\right) \\
& b_{2}=\cos \left(\beta_{x 1}\right) \cos \left(\beta_{x 4}\right)-\sin \left(\beta_{x 1}\right) \cdot \cos \left(\beta_{y 3}\right) \cdot \sin \left(\beta_{x 4}\right) \\
& c_{2}=\cos \left(\beta_{x 1}\right) \cdot \cos \left(\beta_{y 3}\right) \cdot \sin \left(\beta_{x 4}\right)+\sin \left(\beta_{x 1}\right) \cdot \cos \left(\beta_{x 4}\right) \\
& d_{2}=-\cos \left(\beta_{y 3}\right) \cdot \sin \left(\beta_{x 4}\right) w_{z 2}-w_{y} \\
& a_{3}=-\sin \left(\beta_{y 3}\right) \cdot \cos \left(\beta_{x 4}\right) \\
& b_{3}=-\cos \left(\beta_{x 1}\right) \cdot \sin \left(\beta_{x 4}\right)-\sin \left(\beta_{x 1}\right) \cdot \cos \left(\beta_{y 3}\right) \cdot \cos \left(\beta_{x 4}\right) \\
& c_{3}=\cos \left(\beta_{x 1}\right) \cos \left(\beta_{y 3}\right) \cdot \cos \left(\beta_{x 4}\right)-\sin \left(\beta_{x 1}\right) \cdot \sin \left(\beta_{x 4}\right) \\
& d_{3}=-\cos \left(\beta_{y 3}\right) \cdot \cos \left(\beta_{x 4}\right) w_{z 2}-w_{z} .
\end{aligned}
$$

The equation system of the ellipse $e$ in $[x, y, z]$ we can obtain as the result of replacing the coordinates $x_{L}, y_{L}, z_{L}$ in (11) by the right sides of its mathematic formula (5).

In the case when there exists the plane of symmetry of the gable wall and this plane is $(x, z)$ of $[x, y, z]$, which is also the plane of symmetry of the ellipse $w_{j}$, then the measures of the angle $\vec{\beta}_{x 1}$ of $\mathrm{O}_{\mathrm{x} 1}$ and the vector $\vec{w}_{\mathrm{yz}}$ of $\mathrm{T}_{\mathrm{yz}}$ are equal to zero and the coefficients of the formula (12) are reduced and take the following representation

$$
\begin{aligned}
& a_{1}=\cos \left(\beta_{y 3}\right) \\
& b_{1}=0 \\
& c_{1}=\sin \left(\beta_{y 3}\right) \\
& d_{1}=-\sin \left(\beta_{y 3}\right) w_{z 2} \\
& a_{2}=-\sin \left(\beta_{y 3}\right) \cdot \sin \left(\beta_{x 4}\right) \\
& b_{2}=\cos \left(\beta_{x 4}\right) \\
& c_{2}=\cos \left(\beta_{y 3}\right) \cdot \sin \left(\beta_{x 4}\right) \\
& d_{2}=-\cos \left(\beta_{y 3}\right) \cdot \sin \left(\beta_{x 4}\right) w_{z 2} \\
& a_{3}=-\sin \left(\beta_{y 3}\right) \cdot \cos \left(\beta_{x 4}\right) \\
& b_{3}=-\sin \left(\beta_{x 4}\right) \\
& c_{3}=\cos \left(\beta_{y 3}\right) \cdot \cos \left(\beta_{x 4}\right) \\
& d_{3}=-\cos \left(\beta_{y 3}\right) \cdot \cos \left(\beta_{x 4}\right) \cdot w_{z 2} .
\end{aligned}
$$

We can also rely on a matrix of cosines of inclination angles of each axis of the local coordinate system $\left[x_{L}, y_{L}, z_{L}\right]$ and each axis of the global coordinate 
system $[x, y, z]$ while transforming the coordinates of points and equations of directrices from $\left[x_{L}, y_{L}, z_{L}\right]$ into $[x, y, z]$.

\section{Conclusions}

The way enables us to arrange effectively the shell stripes of the free deformed flat folded sheets in the three-dimensional space in conformity with geometrical properties of a regular surface. There are used straight lines and planes normal to this base surface to obtain the surface areas of the strips close to the surface areas distinguished on the base surface - an effective arrangement of the strips. However, it requires accepting appropriate volumes of the overall dimensions of this base surface and the mutual positions of these areas in the directions of these normal straight lines and planes.

In spite of the deformation restrictions of the folded sheets referring to their space shapes close to ruled surfaces characterized by non-positive Gaussian curvature, the way makes possible to arrange the strips so that their general forms would be similar to geometrical surfaces of any sign of the Gaussian curvature. Many compound building shells can be shaped on the base of such created shell structures with various reference surfaces and effective control structures.

Great diversity of the stripe structures can be achieved by diversifying their controlling structure shapes and the mutual positions and curvatures of the stripe directrices contained in the planes of the controlling structures.

Diversified locations and shapes of the stripes as well as a division and mutual displacement of the directrices of the adjacent strips to get a discontinuous shell structure may increase the visual attractiveness of the whole building object. Therefore, the author hopes, there is a need of an integration of walls, windows and shell strips of roof in shapes and positions to obtain attractive and original, innovative compound shall forms and, next, architectural forms of buildings.

It is possible to obtain a further increase of the integration of the general form of the building object by dividing of the stripes into shell segments to get their effective arrangement toward a base surface but such an action requires a compound operative research process whose description goes beyond the paper scope. 


\section{References}

[1] Abramczyk J.: Peculiar Properties of Ruled Surfaces Useful in Shaping Light Gauge Steel Shells, Beyond the Limits of Man, Proceedings of IASS 2013 Symposium, Wrocław, Poland. 2013, s. 1424-1432.

[2] Abramczyk J.: Free forms of light gauge steel shell structures. Lightweight Structures in Civil Engineering; Proc. XVIII Intern. Sem. of IASS Polish Chapter, MICRO-PUBLISHER-C-P Jan B. Obrębski, Warszawa, 2012, s. 48-53.

[3] Abramczyk J.: Multi-segment shell structures. Lightweight Structures in Civil Engineering; Proc. XVIII Intern. Sem. of IASS Polish Chapter, MICRO-PUBLISHER-C-P Jan B. Obrębski, Warszawa, 2012, s. 38-47.

[4] Abramczyk J.: Wpływ kształtu płaskich arkuszy i konstrukcji podpierających zakrzywione przekrycia z blach fałdowych na ich postać geometryczną, doctoral thesis, Rzeszów 2011.

[5] Abramczyk, J. 2014. Principles of geometrical shaping effective shell structures forms, JCEEA t. XXXI, z. 61, nr 1/2014: 48-53, Rzeszów 2014, pp. 5-21. DOI:10.7862/rb.2014.1.

[6] Anpiłogowa W. A., Dechtjar A. C.: Optimalizacja powierchnosti liniejciatych obołociek, PGiIG, Budiwielnik w. 21, Kiew, 1976, pp. 159-162.

[7] Adiłow O., Kowaljew C. H.: Modjelirowanije powierchnosttej c pomośćju setciatoj nomogrammy, PGilG, Budiwielnik w. 20, Kiew, 1975, pp. 150-154.

[8] Bródka J., Garncarek R., Miłaczewski K.: Blachy fałdowe w budownictwie stalowym, Warszawa: Arkady, 1984.

[9] Davies J.M., Bryan E.R.: Manual of stressed skin diaphragm design, Granada, London 1982.

[10] Kornienko L. W.: Optimalnoje parketirowanie połogich transljacionnych obołociek po hektorym napered zadannym usłowijam, PGilG, Budiwielnik w. 25, Kiew, 1978 pp. 57-59.

[11] Michajlenko W. E.: O geometii obołociek w żywoj prirode, Sbornik Prikładnaja geometrija i inżeniernaja grafika, Wyp. 12, „Budiwielnik”, 1971.

[12] Obrębski J. B.: UNIDOM - Space Bar System. Lightweight Structures in Civil Engineering; Proc. XII Intern. Sem. of IASS Polish Chapter: 76-87, Warsaw, MICROPUBLISHER-C-P Jan B. Obrębski, 2006.

[13] Polański S.: Geometria wykreślna Tom 2, PWN, Warszawa 1976.

[14] Przewłocki S. (1982) “Geometria wykreślna w budownictwie”, Arkady, Warszawa.

[15] Reichhart A.: Geometrical and structural shaping of shells made of profiled metal sheets (Monograph in Polish), Oficyna Wyd. Politechniki Rzeszowskiej, Rzeszów 2002.

[16] Reichhart A.: Powłokowe formy architektoniczne z blach fałdowych. Mat. Symp. Z cyklu Nowe osiagnięcia nauki i techniki w budownictwie: Projektowanie koncepcyjne kształtowanie konstrukcji, konstrukcje z blach fałdowych, konstrukcje cięgnowe, Oficyna Wydawnicza Politechniki Rzeszowskiej., Rzeszów 2000, s. 65-72.

[17] Trajdos T.: Matematyka dla inżynierów, WNT, Warszawa, Polska 1981.

[18] Wei-Wen Y.: Cold-Formed Steel Design, John Wiley \& Sons. Inc., Canada 2000. 


\section{PEWIEN SPOSÓB GEOMETRYCZNEGO KSZTALTOWANIA EFEKTYWNYCH FORM STRUKTUR POWLOKOWYCH}

\section{Streszczen i e}

Główną zawartość artykułu stanowi prezentacja sposobu rozmieszczania pojedynczych powłok wykonanych z przekształconych do postaci powłokowej płaskich arkuszy blachy fałdowej i rozmieszczanych $\mathrm{w}$ trójwymiarowej przestrzeni w celu uzyskania ogólnej postaci pewnej struktury zgodnej $\mathrm{z}$ właściwościami geometrycznymi pewnej, wstępnie zakładanej powierzchni geometrycznej zwanej powierzchnia bazową charakteryzującą się dowolnym znakiem krzywizny Gaussa. Sposób pozwala na uzyskanie: a) integracji kształtu i położenia elementów kształtowanego obiektu budowlanego: ścian, okien, dachu powłokowego przez zróżnicowanie ich nachylenia do kierunku pionowego i poziomu, b) efektywnej pracy konstrukcyjnej fałd powłoki w późniejszej fazie obciążeń użytkowych, c)efektywnego rozmieszczenia pasm powłokowych arkuszy względem powierzchni bazowej, d) efektywnego pokrycia powierzchni pasm powłokowych przekształconymi arkuszami fałdowymi. Cele te zostały osiagnięte za pomocą pomocniczych wielościennych utworów zwanych utworami sterującymi, których ściany i krawędzie przyjmują położenie zbliżone do położeń płaszczyzn i prostych normalnych do powierzchni bazowej, tak dokładnie jak to jest możliwe z uwzględnieniem przyjętej dokładności kształtowania. W kolejnym etapie są wyznaczane kierownice pasm w płaszczyznach struktury sterującej utworzonej przez powyższe pomocnicze utwory sterujące. Modele pasm tworzące geometryczną strukturę powłokową są wyznaczane na podstawie kierownic tak, żeby każdy model został zawarty w jednym utworze sterującym. Proponowany sposób może zostać łatwo rozszerzony na bardziej rozbudowane powłokowe struktury w tym struktury segmentowe, które również mogą charakteryzować się dużą integralnością dowolnej liczby elementów kształtowanego obiektu budowlanego.

Słowa kluczowe: struktury powłokowe, powłoki z blach fałdowych, deformacja wstępna arkuszy fałdowych

Przestano do redakcji: 3.02 .2015

Przyjęto do druku:1.12.2015

DOI: $10.7862 / \mathrm{rb} .2015 .137$ 